\title{
Pain catastrophizing in Flamenco dance students at professional dance conservatories
}

\author{
Irene Baena-Chicón 1,2, Sebastián Gómez-Lozano', Lucía Abenza Cano', Alfonso Vargas-Macías³ \\ ${ }^{1}$ Facultad de Deporte. Universidad Católica de Murcia. ${ }^{2}$ Conservatorio Profesional de Danza Pepa Flores de Málaga. ${ }^{3}$ Centro de Investigación Flamenco Telethusa.
}

doi: 10.18176/archmeddeporte.00030

Received: $12 / 10 / 2020$ Accepted: $17 / 12 / 2020$

Key words: Psychological suffering. Injury. Movement. Dance.

\section{Summary}

Introduction: Flamenco is marked by the deep emotional impression it creates and its percussive footwork steps, performed in traditional high-heeled shoes. It places high demands on the dancer which leads to risks of injury, pain and associated emotional repercussions. Catastrophizing is a key factor determining how the context is valued and pain is experienced. The objectives of this study were: firstly, to analyse the general incidence of catastrophizing among flamenco students and secondly, to determine the repercussion this has on catastrophizing in professional practice among dancers who perform on stage even though they are still students.

Material and method: The sample analyses 70 students from the Conservatorios Profesionales de Danza de Andalucía (Andalusian Professional Conservatoires for Dance) (17.67 \pm 5.65 years old); $44.29 \%$ ( $n=31)$ also danced professionally. The dancers completed the Pain Catastrophizing Scale (PCS).

Results: The results do not show significant differences in categories: rumination, magnification, nor in the overall catastrophizing of pain when comparing participants who were dance students with those who also danced professionally. However, in terms of helplessness, there is a significant difference between both groups, with those who danced both as students and professionals displaying higher levels of helplessness than those who were only students.

Conclusions: The artistic professional development on stage before spectators can trigger anxiety states that can have a directly proportional association to the levels of catastrophism. Perhaps being a student at the same time as dancing professionally signifies a greater physical and mental load which can lead to certain psychological processes.

\section{Catastrofismo ante el dolor en estudiantes de baile flamenco de conservatorios profesionales de danza}

\section{Resumen}

Introducción: El baile flamenco se caracteriza por una fuerte impronta emocional y sobre todo por el carácter percutivo de sus zapateados realizados con un calzado tradicional de tacón. Esta danza supone altas demandas de esfuerzo con sus consiguientes riesgos de lesión, dolor y efectos emocionales asociados. El catastrofismo juega un papel esencial en la valoración del contexto y la experiencia del dolor. Este estudio tuvo como objetivos; en primer lugar, analizar la incidencia general del catastrofismo en estudiantes de baile flamenco y; en segundo lugar, determinar la repercusión sobre el catastrofismo de la práctica profesional en aquellas bailaoras que aun siendo estudiantes actúan escénicamente.

Material y método: La muestra analizada consta de 70 alumnas de Conservatorios Profesionales de Danza de Andalucía (17.67 \pm 5.65 años); el 44.29\% ( $n=31)$, también bailaban profesionalmente. Las bailaoras cumplimentaron la Escala de Catastrofismo ante el Dolor (ECD).

Resultados: Los resultados no muestran diferencias significativas en las categorías: rumiación, magnificación, ni en el global del catastrofismo ante el dolor al comparar participantes que sólo eran estudiantes de baile y las que además, tenían carácter profesional. En cambio, en la dimensión de desesperación sí se observa una tendencia significativa entre ambos grupos, estudiantes y profesionales, acentuada en este último grupo.

Conclusiones: El desarrollo profesional artístico en escena ante espectadores puede desencadenar estados de ansiedad

Palabras clave: Dolor psicológico. Lesión. Movimiento. Danza. que pueden llegar a tener una asociación directamente proporcional a los niveles de catastrofismo. Quizás, el hecho de ser estudiante y, a la vez, ejercer la profesión de bailaora suponga una mayor carga física y mental que puede desencadenar determinados procesos psicológicos. 


\section{Introduction}

Flamenco dancing is characterised by strong emotional stamping and by the percussive nature of the footwork performed with traditional high-heeled shoes ${ }^{1}$. The performance of Flamenco requires dancers to exert high levels of effort similar to those observed at elite-level physical sport activities ${ }^{2}$. Therefore, as in the case of ballet ${ }^{3}$, Flamenco dancers are considered to be elite athletes ${ }^{4}$. During a professional performance an average of four stamps on the floor per second are made, which can reach frequencies of up to twelve stamps per second ${ }^{5}$. This imposes high impact stress with its subsequent risks of injury, primarily centred on the feet, knees and back ${ }^{5-7}$.

Injury is a traumatic event which, depending on its extent, can lead to a turning point in the life of anyone doing physical activity ${ }^{8}$. In the world of sport, there is a widespread view that relates pain with athletic performance and injury as a fundamental part of an athlete's life ${ }^{9}$. This is exactly the same with dancing ${ }^{10}$. Encarnación et al. ${ }^{11}$ warn that in ballet, dancers tend to ignore an injury and to carry on dancing. In fact, these artists are taught from an early age that ballet is equivalent to pain, due to its complicated technique, this is particularly true for women as a result of the use of pointe shoes ${ }^{12}$. This attitude means that injuries are not always diagnosed and treated by a medical practitioner and, therefore, could become chronic through incorrect treatment. As a result, ballet dancers are no longer able to continue performing, suffering psychological changes such as state of mind, thoughts and conducts that make rehabilitation difficult.

Pain is the immediate and prolonged effect of an injury ${ }^{8}$. In a study conducted with 75 students of Flamenco, $74.7 \%$ acknowledged having felt pain when dancing Flamenco and 66.7\% further stated that they had an injury ${ }^{13}$. Pain is described as a complex process in which biological and psychological factors are part of an emotional and sensorial experience at an individual level ${ }^{9}$. However, its relationship is not directly proportional to the severity of the injury, given that other factors may come into play such as age, level of education, race, socio-economic status, depression, resilience, pain catastrophizing and attitudes to treatment. For athletes, the fact that they have experienced pain during training is often considered with satisfaction, taking this as an indication of effort and that they have pushed their performance to its limits ${ }^{9}$. However, dancers are not always able to differentiate between the pain of their routine training and the pain of an actual injury ${ }^{14}$.

In order to improve the results of the treatment and the extent of the pain, psychological intervention programs could be implemented which, irrespective of demographic factors (age, sex, place of residence), could be feasible even taking into account the psychosocial factors characteristic of dancers ${ }^{15}$. However, in order to obtain optimal results, it is first necessary to quantify the extent to which pain coping strategies are present in specific populations of patients.

Catastrophizing is a tendency to magnify the perception of pain with a negative mindset, during actual or anticipated pain experience ${ }^{16}$.
Its role is essential with regard to the assessment of the context and the experience of pain. It is related to increased pain sensitivity, intensity and disability, leading to an emotional state associated with anxiety and depression ${ }^{17}$. A number of studies report that catastrophizing may change during psychological interventions through improvements in pain, psychological state and physical capacity ${ }^{8}$.

When examining the psychosocial factors associated with dancing stress, it can be appreciated that it is essential to understand the main causes of stress and the the main ways in which dancers try to cope with these stressors ${ }^{8}$. For their physical wellbeing, Patterson et al. ${ }^{19}$ indicate that stress in life and social support are exponential contributors. Different cultures also have an influence, given that dancers from different countries may experience different stressors and develop alternative ways of coping with pain.

Catastrophizing scores have been studied in different types of dancing, basically in ballet and contemporary dancers $9,11,12,14,18,20-25$ and specifically in traditional Irish dancers ${ }^{10,26}$. In contrast, we are not aware of any studies made on Flamenco dancing. Despite the fact that there are studies that detail important cases of injuries and pain in Flamenco dancing ${ }^{5,6,27-30}$ there are few studies that analyse the pain beyond the anatomical perspective. Lupiáñez $z^{31}$ holds that Flamenco dancers have no mental training to cope with cognitive distortions that appear during performance. Moreover, it has been confirmed that Flamenco artists suffer from anxiety symptoms such as sweating during the shows. This leads to symptoms such as foot numbness or trembling knees, making it impossible to perform the footwork with the desired skill and technique 32 .

Therefore, the study objectives are to analyse the level of catastrophizing of the official Flamenco women dance students and to determine whether or not there are any differences in the catastrophic thinking between professional and non-professional female dancers.

\section{Material and method}

\section{Participants}

The study sample comprised 70 female students of artistic studies at the Conservatorios Profesionales de Danza de Andalucía (Professional Dance Conservatories in Andalucia), in the specialty of Flamenco dancing. Within this group of students, $44.29 \%(n=31)$ also danced professionally. The age ranged from 12 to 30 years, with a mean age of $17.67 \pm 5.65$ years. On a weekly basis, they dedicated an average of 8.19 \pm 3.30 hours to Flamenco dance practice.

Non-probability consecutive sampling was used to select participants, selecting all possible accessible subjects who met the inclusion criteria. These were: 1) Student of a professional dance conservatory, specialising in Flamenco dancing; 2) At least two years of experience in Flamenco dancing; and 3) Active and dedicating at least 6 hours a week to practising Flamenco dancing (rehearsals, classes / or shows) The exclusion criteria were: 1) No injury at the time of the study; and 2) No injury in the last 6 months prior to the study. 
Prior to the investigation, approval was obtained from the ethics committee of the Universidad Católica San Antonio (Catholic University of St. Anthony), Murcia. In all cases, the study met the requirements of the Code of Ethics of the World Medical Association (Declaration of Helsinki) for trials with human subjects. Furthermore, all the subjects taking part in the trial, or legal guardians in the case of minors, signed an informed consent prior to the collection of data, explaining the study objectives, as well as the conditions in which the measurements would be taken and the confidential nature of the information obtained.

\section{Instruments}

The study used the Pain Catastrophizing Scale (PCS) ${ }^{33}$, specifically its Spanish version Escala de Catastrofismo ante el Dolor (ECD) ${ }^{8}$, a 13-item self-administered questionnaire to assess three factors: Rumination (I can't stop thinking about how much it hurts), Magnification (It's awful and I feel that it overwhelms me) and Helplessness (it's awful and I feel that it's stronger than me). The score for each item is from 0 (not at all) to 4 (all the time) obtaining a maximum score of 52 points: low scores indicate a low level of catastrophic thinking while high scores indicate a high level of catastrophic thinking. Overall, this scale has a strong internal consistency with a Cronbach's alpha of $0.82^{16}$.

\section{Procedure}

This is a cross-sectional, descriptive study in which all the variables are assessed at the same time. A direct interview was made based on questions regarding socio-demographic details (age, sex) and related to dance practice (level of education, years of experience, hours of practice per week, student and professional - only student). Likewise, the Flamenco dancers completed the Spanish version of the PCS in the presence of the principal investigator, first giving them a brief justification of the investigation and expressing the strict confidentiality of the results obtained. The questionnaire was conducted in the course of the first quarter of 2020. All data were obtained in a single 20-minute session for each group of students, prior to commencing a dance class in their reference classroom.

\section{Data analysis}

A descriptive analysis was performed using the SPSS 16.0 statistical program, obtaining the characteristic parameters, mean and standard deviation, for the quantitative variables. To analyse the representativeness of the arithmetic means, the Pearson's coefficient of variation was used.

A Student's paired T test was used to compare two means for these same variables, in order to make a comparison between the means for the group of students and the group of professionals.

\section{Results}

When comparing the 3 dimensions of pain catastrophizing between participants who were only dance students and those who were students and professionals at the same time, no significant differences were found in the categories: rumination, magnification or in the overall pain catastrophizing score. However, with regard to the helplessness dimension, a significant trend was observed between the non-professional and professional groups, which was accentuated in this latter group (Table 1)

Complementary to Table 1, and following a separate analysis of each of the 13 items, statistically significant differences were found in 3 items:

- Rumination of the four items making up this category, for item 1. I worry about whether the pain will end ( $t=1.968 ; p=0.025)$ and for item 3. The pain is terrible and I think it's never going to get any better ( $\mathrm{t}=-1.998 ; p=0.026$ ).

- Magnification of the four items making up this category, for item 7. I am reminded of past painful experiences; where a significant tendency to accentuate these thoughts or feelings is recorded for the group of professional Flamenco dancers ( $t=-1.01, p<0.1)$.

\section{Discusión}

The aim of this study was to identify the pain catastrophizing level in Flamenco dance students, while also analysing the differences in each of the catastrophizing dimensions (rumination, magnification and

Table 1. Descriptive and comparative statistics of T-Student measurements

\begin{tabular}{|c|c|c|c|c|c|}
\hline Variables & $\begin{array}{c}\text { Sample } \\
(n=70)\end{array}$ & $\begin{array}{l}\text { Students } \\
(n=39)\end{array}$ & $\begin{array}{c}\text { Students } \\
\text { professionals }(n=31)\end{array}$ & $\begin{array}{l}t \text { value } \\
(p<0,05)\end{array}$ & $\begin{array}{l}\text { Confidence } \\
\text { interval } 95 \%\end{array}$ \\
\hline Rumination & $1.85 \pm 1.06$ & $1.87 \pm 1.08$ & $1.83 \pm 1.05$ & $\begin{array}{l}t=0.135 \\
p=0.893\end{array}$ & $-0.477 ; 0.546$ \\
\hline Magnification & $1.57 \pm 0.99$ & $1.50 \pm 1.00$ & $1.67 \pm 1.00$ & $\begin{array}{l}t=-0.712 \\
p=0.479\end{array}$ & $-2.979 ; 0.979$ \\
\hline Helplessness* & $1.29 \pm 0.82$ & $1.19 \pm 0.67$ & $1.41 \pm 0.97$ & $\begin{array}{l}t=-1.1 \\
p<0.1\end{array}$ & $-2.870 ; 2.376$ \\
\hline Catastrophizing & $19.89 \pm 10.54$ & $19.10 \pm 9.28$ & $20.87 \pm 12.04$ & $\begin{array}{l}t=-0.69 \\
p=0.24\end{array}$ & $-6.850 ; 3.313$ \\
\hline
\end{tabular}

*slight or moderate significance level. 
helplessness) for female students compared to those dancers who were performing on stage.

The results obtained do not support those reported by Cahalan et al. ${ }^{10}$ in which, in a sample of elite Irish dancers, the factors significantly related to severe injuries (1 rehearsal or performance day lost due to injury and more than 21 days for recovery) were: female sex, subjective health and psychosocial complaints, as well as heightened catastrophizing. Along these lines, catastrophizing has already been shown to be a pain predictor for athletes and sedentary individuals alike, and to explain the differences in the perception of pain between men and women ${ }^{34}$. Likewise, in the study conducted by Etherton et $a{ }^{3.5}$ with a sample of university students subjected to an induced pain experience, they also found that the mean subjective pain was higher for women than for men. However, men exhibited greater cardiovascular reactivity in response to the painful task compared to women, while failing to fully recover to baseline levels.

Analysing the three categories: rumination, magnification and helplessness, there is a significant trend only in the last factor of helplessness ( $\mathrm{t}=-1.1 ; p<0.1)(\mathrm{Cl} 95 \%$ : $-2,870 ; 2,376)$. This is more evident in the professional group of Flamenco dancers. However if, moreover, the statistical results of the items of this category are observed: 1. I worry about whether the pain will end and 3. The pain is terrible and I think it's never going to get any better, there are a high level of significant differences between both groups ( $\mathrm{t}=1.968 ; p=0.025)$ and $(\mathrm{t}=-1.998$; $p=0.026$ ) respectively for each item. This fact relates to the Locus of control concept ${ }^{35}$ : not knowing the origin of the cause of the event or not feeling in control of one's own fate can be related to episodes of depression. This component of the helplessness category, showing the incapacity of individuals in the face of painful situations, is clearly reflected in our study in which professional Flamenco dancers demonstrate a feeling of impotence compared to non-professional student dancers.

Moreover, within the magnification category, in relation to: the exaggeration of unpleasant painful situations and the expectations of negative consequences ${ }^{8}$ there is item 7 . I am reminded of past painful experiences; where the group of professional Flamenco dancers shows a significant tendency to accentuate these thoughts or feelings ( $t=-1.01$, $p<0.1)$. This tendency, although moderate, reflects a differentiating factor between Flamenco dancing as part of an educational curriculum, and exposure to another type of responsibility before an audience.

Perhaps being a student and, at the same time, working as a professional Flamenco dancer entails greater physical and mental stress that may trigger certain psychological processes such as increased anxiety and a greater concern and impression with regard to feelings of pain associated with their situation, in a similar way to the findings reported in studies that relate anxiety and catastrophizing in injured athletes ${ }^{36,37}$. However, in the work of Paparizos et al. ${ }^{12}$ that relates catastrophizing and pain, by inducing pain in a group of female dancers who were divided into three levels (advanced, intermediate and beginners). The advanced dancers showed greater tolerance to pain than the beginners.
We found that, within the Flamenco dance technique, there may exist a somatization specificity between anxiety or stage fright and certain dimensions of pain catastrophizing. Studies of athletes have shown how there is a close correlation between competition anxiety and pain catastrophizing conditions ${ }^{16}$. This correlation in athletes leads us to detect quite a wide field of action for professional and non-professional Flamenco dancers alike directed at improving their performance from a physiological and psychological point of view. The demands of this discipline are well-known, as well as the high levels of aversive stimuli that generate stress and unworkable responses by the Flamenco dancers lacking mental training to cope with them ${ }^{32}$. Despite this, there are no studies to assess catastrophizing as an indicator associated with coping with the pain in a dance specialty such as Flamenco. We would therefore highlight the interest of our study in order to make it possible to continue to progress in this line of investigation.

It should be underscored that the rating of catastrophizing, as well as its three factors (rumination, magnification and helplessness) could prove extremely useful to the dancer population where pain, associated with normal practice or due to injury, is a daily element that has been empirically demonstrated ${ }^{11}$. Furthermore, the psychological models that explain pain from a cognitive perspective have shown that negative thinking may hinder rehabilitation due to the resulting emotional imbalance ${ }^{38}$, lending support to the idea that.the control of catastrophizing in athletes may help to reduce negative outcomes. As is the case with athletes, Flamenco dancers with high catastrophizing levels may not be correctly using their attentional capacity due to intrusive pain-related thoughts, as indicated by Sullivan et al. ${ }^{34}$. In this regard, psychological training programs stand as an effective tool to reduce catastrophizing in sport, including psychological techniques such as full attention, relaxation, cognitive restructuring and visualization ${ }^{39}$.

With regard to the limitations and future lines of investigation present in the study, it should be highlighted that the sample only considers women and it would therefore be necessary to replicate the study on samples of men and also on other dance specialties. It is considered necessary to develop future lines of study on the perception of pain and catastrophizing with professionals who have completed their academic stage of training. A further proposal is to analyse pain catastrophizing at different moments of the academic course (start, middle, end) and try to correlate this with the type and number of potentially stressful stimuli present at each moment in time (rehearsal times, exams, auditions, performances, role in the show). It would also be of interest to study the differences in pain catastrophizing, algias and sport injuries between dancers of different levels and sexes.

\section{Conclusions}

Due to the high physical demands of Flamenco dancing, those who practice this form of dancing have subjective perceptions of pain that are comparable to other sport and dancing activities. It was observed that those subjects studying Flamenco and also performing professio- 
nally show greater negative perception in those aspects characterising catastrophic thinking such as rumination, magnification and particularly helplessness to cope with the pain, with a moderately significant trend. It therefore appears evident that stage performance in front of an audience may trigger states of anxiety that may have an association that is directly proportional to the catastrophizing levels.

\section{Acknowledgements}

We would like to thank the Conservatorios Profesionales de Danza in Andalucia for their collaboration in order to conduct the questionnaires among their students of Flamenco dancing, allowing us to carry out this study. Our thanks also go to the Centro de Investigación Flamenco Telethusa (PI/A3/2018) for its help, while this is a project funded by the said Centre to promote Flamenco as an intangible universal heritage of humanity.

\section{Conflict of interests}

The authors have no conflict of interest at all.

\section{Bibliography}

1. Baena-Chicón I. Tratamiento coreográfico en el baile Flamenco. Rev Cent Inv Flam Tele. 2016;9:11-4. doi:10.23754/telethusa.091102.2016.

2. Pedersen ME, Wilmerding MV, Kuhn BT, Enciñias-Sandoval E. Energy requirements of the american professional flamenco dancer. Med Probl Perform Art. 2001;16:47-52.

3. Koutedakis $Y$, Jamurtas A. The dancer as a performing athlete. Sports Medicine. 2004; 34:651-61.

4. Vargas Macías A, González Montesinos JL, Mora Vicente J, Lozano SG. La necesidad de la preparación física en el baile flamenco. Rev Cent Inv Flam Tele. 2008;1:4-6.

5. Vargas A. El baile flamenco: estudio descriptivo, biomecánico y condición. Universidad de Cádiz. 2006.

6. Pedersen ME, Wilmerding $\mathrm{V}$. Injury profiles of student and professional flamenco dancers. J Danc Med Sci. 1998;2:108-14.

7. Voloshin AS, Bejjani FJ, Halpern M, Frankel VH. Dynamic loading on flamenco dancers: a biomechanical study. Hum Mov Sci. 1989;8:503-13. doi:10.1016/0167-9457(89)90033-X.

8. Olmedilla Zafra A, Ortega Toro E, Abenza Cano L. Validación de la escala de catastrofismo ante el dolor (Pain Catastrophizing Scale) en deportistas españoles. Cuad Psicol del Deport. 2013;13:83-94. doi:10.4321/S1578-84232013000100009.

9. Harrison C, Ruddock-hudson M. Perceptions of Pain, Injury, and Transition-Retirement. The Experiences of Professional Dancers. J Danc Med Sci. 2017;21:43-53.

10. Cahalan R, O'Sullivan P, Purtill H, Bargary N, Ni Bhriain O, O'Sullivan K. Inability to perform because of pain/injury in elite adult Irish dance: A prospective investigation of contributing factors. Scand J Med Sci Sport. 2016;26:694-02. doi:10.1111/sms.12492.

11. Encarnacion ML, Meyers MC, Ryan ND, Pease DG. Pain Coping Styles of Ballet Performers. J Sport Behav. 2000;23:20-32.

12. Paparizos A, Tripp D, Sullivan M, Rubenstein M. Catastrophizing and pain perception in recreational ballet dancers. J Sport Behav. 2004;28:35-50.

13. Baena-Chicón I, Gómez-Lozano S, Abenza-Cano L, Abadía García de Vicuña O, Fernández-Falero MR, Vargas-Macías A. Las algias como factor predisponente de lesión en estudiantes de baile flamenco. CCD. 2020;15:245-53. https://doi.org/10.12800/ccd. v15i44.1466.

14. Anderson R, Hanrahan SJ. Dancing in pain: pain appraisal and coping in dancers. $J$ Danc Med Sci. 2008;12:9-16.

15. Sciascia A, Waldecker J, Jacobs C. Pain catastrophizing in collegiate athletes. J Sport Rehabil. 2018;29:168-73.
16. Olmedilla A, Ortega E, Boladeras A, Abenza L, Esparza F. Relaciones entre catastrofismo ante el dolor y ansiedad competitiva en deportistas. Therapy. 2008;4:45-51.

17. Peñarroya Baulíes A, Ballús-Creus C, Pérez Martínez J. Diferencias en el uso de las estrategias de afrontamiento, el catastrofismo y el estado de ánimo en función del tiempo de evolución del dolor crónico. Rev la Soc Esp del Dolor. 2011;18:77-83.

18. Noh Y-E, Morris T, Andersen MB. Occupational stress and coping strategies of professional ballet dancers in Korea. Med Probl Perform Art. 2009;24:124-34.

19. Patterson EL, Smith RE, Everett JJ, Ptacek JT. Psychosocial factors as predictors of ballet injuries: Interactive effects of life stress and social support. J Sport Behav. 1998;21:101.

20. Hamilton LH, Hamilton WG, Meltzer JD, Marshall P, Molnar M. Personality, stress, and injuries in professional ballet dancers. Am J Sports Med. 1989;17:263-67. doi:10.1177/036354658901700219.

21. Mainwaring LM, Finney C. Psychological Risk Factors and Outcomes of Dance Injury. J Danc Med Sci. 2017;21:87-96. doi:10.12678/1089-313X.21.3.87.

22. Noh YE, Morris T, Andersen MB. Psychological intervention programs for reduction of injury in ballet dancers. Res Sport Med. 2007;15:13-32. doi:10.1080/15438620600987064.

23. Riskind JH, Long D, Duckworth R, Gessner T. Clinical Case Study: Clinical Use of the Looming Vulnerability Construct for Performance Anxiety in a Dance Recital. J Cogn Psychother. 2004;18:361-6. doi:10.1891/jcop.18.4.361.64000.

24. Tajet-Foxell B, Rose FD. Pain and pain tolerance in professional ballet dancers. Br J Sports Med. 1995;29:31-4. doi:10.1136/bjsm.29.1.31.

25. Walker IJ, Nordin-Bates SM. Performance anxiety experiences of professional ballet dancers: the importance of control. J Dance Med Sci. 2010;14:133-45.

26. Cahalan R, Purtill H, O'Sullivan P, O'Sullivan K. A Cross-Sectional Study of Elite Adult Irish Dancers. J Danc Med Sci. 2015;19:31-43. doi:10.12678/1089-313X.19.1.31.

27. Bejjani FJ, Halpern N, Pio A, Domínguez R, Voloshin A, Frankel VH. Musculoskeletal demands on flamenco dancers: a clinical and biomechanical study. Foot ankle Int. 1988;8:254-63. doi:10.1177/107110078800800505

28. Castillo-López JM, Munuera-Martínez PV, Algaba-Guisado C, Reina-Bueno M, Salti-Pozo $\mathrm{N}$, Vargas-Macías A. A pathologic disorders of the foot in professional female flamenco dancers. J Am Podiatr Med Assoc. 2016;106:54-59. doi:10.7547/14-111.

29. Castillo-López JM, Vargas-Macías A, Domínguez-Maldonado G, Lafuente-Sotillos G, Ramos-Ortega J, Palomo-Toucedo IC, et al. Metatarsal pain and plantar hyperkeratosis in the forefeet of female professional flamenco dancers. Med Probl Perform Art. 2014;29:193-97.

30. Echegoyen S, Acuña E, Rodríguez C. Injuries in students of three different dance techniques. Med Probl Perform Art. 2010;25:72-4.

31. Lupiáñez M. Cómo afecta la distorsión cognitiva a la ejecución del bailaor flamenco. Sinf Virt. 2016;30:1-6.

32. Lupiáñez M, Hoces R. Ansiedad escénica y flamenco. Rev Cent Inv Flam Tele. 2016;9:5-9.

33. Sullivan MJL, Bishop SR, Pivick J. The pain catastrophizing scale: Development and Validation. Psychol Assess. 1995;7:524-32.

34. Sullivan MJL, Tripp DA, Rodgers WM, Stanish W. Catastrophizing and pain perception in sport participants. J App/ Sport Psychol. 2000;12:151-67.

35. Etherton J, Lawson M, Graham R. Individual and gender differences in subjective and objective indices of pain: gender, fear of pain, pain catastrophizing and cardiovascular reactivity. Appl Psychophys Biof. 2014;39:89-97.

36. Cano LA, Zafra AO, Toro EO, Ros FE. Estados de ánimo y adherencia a la rehabilitación de deportistas lesionados. Apunt Med l'Esport. 2009;44:29-37.

37. Tripp DA, Stanish WD, Reardon G, Coady C, Sullivan MJL. Comparing postoperative pain experiences of the adolescent and adult athlete after anterior cruciate ligament surgery. J Ath/ Train. 2003;38:154-7.

38. Daly JM, Brewer BW, Van Raalte JL, Petitpas AJ, Sklar JH. Cognitive appraisal, emotional adjustment, and adherence to rehabilitation following knee surgery. J Sport Rehabil. 1995:4:22-30.

39. Galambos SA, Terry PC, Moyle GM. Incidence of injury, psychological correlates, and injury prevention strategies for elite sport. En: Proceedings of the 2006 Joint Conference of the Australian Psychological Society and the New Zealand Psychological Society: Psychology Bridging the Tasman: Science, Culture and Practice. Australian Psychological Society. 2006; p. 125-9. 